\title{
The anti-arthritic and anti-inflammatory activities of aqueous extract powder bark of Anthocleista schweinfurthii Gilg (Loganiaceae)
}

\author{
Djova Steve Valdi 1*, Nyegue Maximilienne Ascension ${ }^{2}$, Etoa François-Xavier ${ }^{2}$ \\ ${ }^{1 *}$ Department of Biochemistry, University of Yaounde I, PO Box 812 Yaounde, Cameroon. \\ ²Department of Microbiology, University of Yaounde I, PO Box 812 Yaounde, Cameroon.
}

\begin{abstract}
Aqueous extract bark of Anthocleista schweinfurthii (ASE) was investigated for anti-arthritic, anti-inflammatory activities and phytochemicals screening. Phytochemical screening was carried out according, to LC-MS procedures, the anti-inflammatory effect of ASE was evaluated in vitro inhibition of 15-lipoxygenase (15-LOX) enzyme and proteinase inhibiting action assays. The anti-arthritic activity was performed according to the Bovine Serum Albumin (BSA) test. The chemical composition of ASE showed that it was mainly composed of isocyanate, biphenyltriol, methoxyflavanone, soscoparin and glucopyroside. In the anti-inflammatory assays, ASE showed selective inhibition of 15-lipooxygenase with IC 50 value of $37.19 \pm 0.54 \mu \mathrm{g} / \mathrm{mL}$ and moderate activity against the inhibition of proteinase action with $\mathrm{IC}_{50}$ value of $244.33 \pm 2.08 \mu \mathrm{g} / \mathrm{mL}$. Both the methods showed that the ASE posses good anti-inflammatory activity. ASE had strong in vitro anti-arthritic activity with IC 50 of $13.67 \pm 0.88 \mu \mathrm{g} / \mathrm{mL}$, the positive control Diclofenac had IC 50 value of $4.66 \pm 0.33 \mu \mathrm{g} / \mathrm{mL}$. The result of this study justified the use of this plant in traditional Cameroonian medicine in the treatment of inflammation. ASE may offer a new source of potential therapeutic agents for the effective treatment of arthritis and inflammation.
\end{abstract}

Keywords: Anthocleista schweinfurthii, phytochemical screening, anti-arthritic activity, anti-inflammatory activity,

Article Info: Received 20 Oct 2018; Review Completed 03 Dec 2018; Accepted 04 Dec 2018; Available online 15 Dec 2018

\section{Cite this article as:}

Djova SV, Nyegue MA, Etoa FX, The anti-arthritic and anti-inflammatory activities of aqueous extract powder bark of Anthocleista schweinfurthii Gilg (Loganiaceae), Journal of Drug Delivery and Therapeutics. 2018; 8(6-s):174-181 DOI: http://dx.doi.org/10.22270/jddt.v8i6-s.2212

*Address for Correspondence:

Djova Steve Valdi, Department of Biochemistry, University of Yaounde I, PO Box 812 Yaounde, Cameroon. Email: djova.stevevaldi@yahoo.fr

\section{INTRODUCTION}

Inflammation is a defense response of our body which involves a complex reaction of vascularised tissues to infection, allergens, toxin exposure and cell injury ${ }^{1,2}$ Conversely, uncontrolled inflammatory response is the main cause of a vast and continuous disorders inclusing cancer, septic shock, diabetes, atherosclerosis, obesity, heart disease, age-related muscular degeneration, chronic obstructive pulmonary disease, multiple sclerosis, arthritis, rheumatoid arthritis $3,4,5$.

Rheumatoid arthritis is a chronic, systematic inflammatory disease predominanatly affecting the joints and periarticular tissues ${ }^{6}$. Currently, steroid drugs, non steroidal anti-inflammatory drugs (NSAIDs) and immunosuppressants, usually used for the relief of inflammatory diseases, require long-term treatment and their use is often associated with serious side effects such as bleeding, gastrointestinal and peptic ulcers ${ }^{7}$. Hence, continuous search for the development of potent anti-inflammatory drugs with fewer side effects is necessary from medicinal plants.
A. schweinfurthii is a plant of the Loganiaceae family, it is a source of traditional recipe for the treatment of male and female fertility problems in Togo, Nigeria, Cameroon, Gabon and Equatorial Guinea ${ }^{8}$. The decoction of the bark of A. schweinfurthii is used for the treatment of sexually transmitted infections ${ }^{9}$. A decoction of barks of root and leaves of $A$. schweinfurthii in Tanzania, is used for the treatment of malaria. A decoction of bark and leaves of $A$. schweinfurthii is used in Tanzania for the treatment of pain, injury and inflammatory diseases 9,10 . In Cameroon, Gabon, Equatorial Guinea, Congo, and Tanzania, a decoction of $A$. schweinfurthii bark is used for the treatment of microbial infections and bronchitis ${ }^{11}$. In Congo, the decoction of bark of $A$. schweinfurthii is used to treat hernia ${ }^{12}$. In Nigeria, $A$. djalonensis is used in traditional medicine to treat breast cancer ${ }^{13}$. In Cameroon, the decoction of bark of $A$. schweinfurthii commonly known as "Bopolopolo" in the Douala language is used for the treatment of gastrointestinal disorders, gastric ulcers, abdominal pain, A. schweinfurthii is used for its galactogenic properties ${ }^{9,14}$.

The in vitro antioxidant activity, cytotoxicity and genotoxicity of extracts from the leaves and barks of $A$. 
schweinfurthii have been already done ${ }^{15}$. Djeussi et al ${ }^{16}$. evaluated the antibacterial properties of the methanol extract of A. schweinfurthii; the vasoconstrictor and inotropic effects induced by the root bark extracts of $A$. schweinfurthii was investigated by Ngombe et al ${ }^{17}$. A new steroid, schweinfurthiin, two known compounds, bauerenone, bauerenol and xanthones were isolated in the dichloomethane/methanol extract of the roots of $A$. schweinfurthii by Mbouangouere et al18. The acute and subacute toxicity of the aqueous extract of $A$. schweinfurthii bark was investigated by Christophe et al $^{9}$. However, as far as known, no work has been devoted to the study of the anti-arthritic and anti-inflammatory activities of aqueous extracts of $A$. schweinfurthii. Therefore, the aim of the present study was to evaluate the anti-arthritic and the anti-inflammatory activities of aqueous extract powder barks of Anthocleista schweinfurthii Gild (Loganiaceae) .

\section{MATERIALS AND METHODS}

\section{Plant material and extraction procedure}

A. schweinfurthii plant was collected at Loum in the Littoral region of Cameroon in August 2016, it is commonly known in Cameroon as "Betbreu" in Medumba local language and "Bopolopolo" in Douala local language. The plant identification was done at the Cameroon National Herbarium by comparison with specimen number 52349/HNC of $A$. schweinfurthii Gild (Loganiaceae).

The barks of $A$. schweinfurthii were air-dried for one week at room temperature and weighed. The sample were then ground to fine powder in a mortar and $500 \mathrm{~g}$ of dried powder was soaked for 48 hours in water. The mixing was filtered through Whatman No. 1 filter paper and lyophilized using the lyophilizator Biobase. Then, the aqueous extracts of $A$. schweinfurthii was collected in Eppendorf tubes and preserved in a refrigerator at $4{ }^{\circ} \mathrm{C}$ for further use.

\section{LC-MS procedures}

LS-MS analysis of OSE was carried out following a modified method of Abay et al ${ }^{19}$. High resolution mass spectra were obtained with an OTOF Spectrometer (Bruker, Germany) equipped with a HESI source. The spectrometer was operated in positive mode (mass range: 100-1000, with a scan rate of $1.00 \mathrm{~Hz}$ ) with automatic gain control to provide high-accuracy mass measurements within $2 \mathrm{ppm}$ deviation using Na Formate as calibrant. The spectrometer was attached to an Ultimate 3000 (Thermo Fisher, USA) HPLC system consisting of LC-pump, Diode Array Detector (DAD) $(\lambda=260 \mathrm{~nm})$, auto sampler (injection volume $5 \mu \mathrm{L}$ ). MS analyses were performed in multiple reaction monitoring (MRM) mode by measuring the fragmentation products of the protonated pseudomolecular ions of COC, $\mathrm{BE}$ and EME and their internal standards in three different fragmentation windows. The ESI voltage was set at $4.5 \mathrm{kV}$. Parameters were optimised by injection of known amounts of the extract and evaluating retention times, analyte response, peak widths and shapes. $\mathrm{C}_{18}$ reversed-phase column oven $\left(30^{\circ} \mathrm{C}\right)$ was used. The isocratic mobile phase was made up of two solvents water/AcN at different concentration water/AcN 95:5 and water/AcN 90:10. The starting eluent was used for equilibration of the column. Nitrogen was used as nebulising gas at a pressure of $40 \mathrm{psi}$. Dry gas debit was set at $8 \mathrm{~L} / \mathrm{min}$ and capillary temperature at $200{ }^{\circ} \mathrm{C}$.

\section{Anti-inflammatory assays}

\section{Inhibition of 15-lipoxygenase (15-LOX) enzyme assay}

The assay was performed according to a previously described procedure by Pinto et $\mathrm{al}^{20}$ and Delong et $\mathrm{al}^{21}$ with slight modifications. The assay measures the $\mathrm{Fe}^{3+} / x y l e n o l$ orange complex at $560 \mathrm{~nm}$ formed when the extract reacts with the assay reagents. Briefly, 15-LOX from Glycine max was incubated with compounds or standard inhibitor at $25{ }^{\circ} \mathrm{C}$ for $5 \mathrm{~min}$. Then linoleic acid (final concentration, $140 \mathrm{mM}$ ) in Tris-HCl buffer ( $50 \mathrm{mM}, \mathrm{pH} 7.4)$ was added and the mixture was incubated at $25{ }^{\circ} \mathrm{C}$ for an additional $20 \mathrm{~min}$ in the dark. The reaction was terminated by the addition of $100 \mathrm{~mL}$ of FOX reagent consisting of sulphuric acid $(30 \mathrm{mM})$, xylenol orange $(100 \mathrm{mM})$, iron (II) sulphate $(100 \mathrm{mM})$ in methanol/water $(9: 1)$. For the control, only LOX solution and buffer were pipetted into the wells. Blanks contained the enzyme LOX during incubation, but the substrate (linoleic acid) was added after the FOX reagent. The LOX inhibitory activity was evaluated by calculating the percentage of the inhibition of hydroperoxide production from the changes in absorbance values at $560 \mathrm{~nm}$ after $30 \mathrm{~min}$ at $25^{\circ} \mathrm{C}$.

$\%$ inhibition $=\left(\left(\mathrm{A}_{\text {control }}-\mathrm{A}_{\text {blank }}\right)-\left(\mathrm{A}_{\text {sample }}-\mathrm{A}_{\text {blank }}\right) /\left(\mathrm{A}_{\text {control }}-\right.\right.$ Ablank)) x100

Where, $A_{\text {control }}$ is the absorbance of control well, $A_{\text {blank }}$ is the absorbance of blank well and Asample is the absorbance of sample well.

\section{Proteinase Inhibitory Action}

The anti-proteinase activity of ASE was determined using the method of Oyedepo et $\mathrm{al}^{22}$ with slight modifications. The reaction mixture $(2 \mathrm{~mL})$ was containing $0.06 \mathrm{mg}$ trypsin, $1 \mathrm{~mL}$ of $20 \mathrm{mM}$ Tris $\mathrm{HCl}$ buffer (pH 7.4) and $1 \mathrm{~mL}$ test sample of different concentrations. The reaction mixture was incubated at $37^{\circ} \mathrm{C}$ for $5 \mathrm{~min}$ and then $1 \mathrm{~mL}$ of $5 \%(\mathrm{~W} / \mathrm{V})$ casein was added. The mixture was incubated for an additional $20 \mathrm{~min}, 2 \mathrm{~mL}$ of $70 \%$ perchloric acid was added to terminate the reaction. Cloudy suspension was centrifuged and the absorbance of the supernatant was read at $210 \mathrm{~nm}$ against buffer as blank. The experiment was performed in triplicate. The percentage of inhibition of proteinase inhibitory activity was calculated.

\section{Anti-arthritic assay}

\section{Bovine Serum Albumin (BSA) denaturation assay}

Protein denaturation was performed as described by Sakat et $\mathrm{al}^{23}$ with slight modifications. The test solution consisting of $1 \mathrm{~mL}$ of different concentrations of extracts preparation ranging from 0.5 to $1.5 \mathrm{mg} / \mathrm{mL}$ or standard Diclofenac sodium 0.1 and $0.25 \mathrm{mg} / \mathrm{mL}$ was mixed with 1 $\mathrm{mL}$ of egg albumin solution $(1 \mathrm{mM})$ and incubated at $27 \pm 1$ ${ }^{\circ} \mathrm{C}$ for $15 \mathrm{~min}$. Denaturation was induced by keeping the reaction mixture at $70{ }^{\circ} \mathrm{C}$ in a water bath for $10 \mathrm{~min}$. After cooling, the turbidity was measured using the Jenway 6305 spectrophotometer at $660 \mathrm{~nm}$. Percentage inhibition of denaturation was calculated from control where no drug was added. Each experiment was done in triplicate.

\section{Statistical analysis}

The results are presented as means of three experiments. Statistical significance between groups was calculated by using a paired t-test with GraphPad Prism software (version 7). Values were expressed as mean \pm SD and differences were considered significant statistically if $P<0.05$. 


\section{RESULTS}

Figure 1 resumes the number of phytoconstituents present in the extract by comparing with the blank.

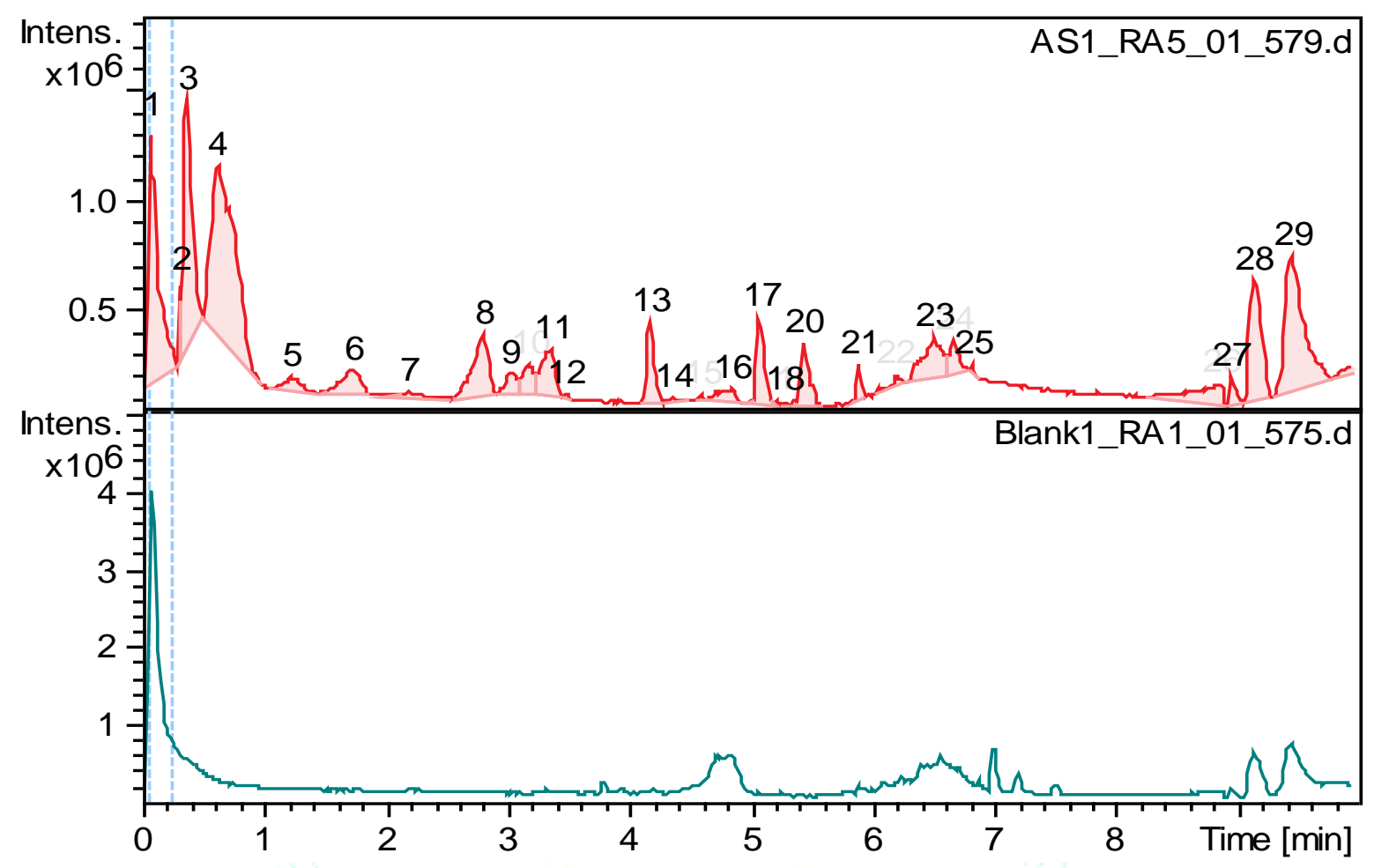

Figure 1: LC-MS chromatogram obtained from ASE

The compounds constituting the ASE were identified through interpretation of their mass spectrum obtained by $\mathrm{LC} / \mathrm{MC}$ in comparison with previously reported data from the literature. The compounds were identified from their protonated molecular ion $[\mathrm{M}]{ }^{+}$. The figure 1 shown that ASE exhibited presence of compound 2 to compound 25 . The compounds with high amount were also identified in the case of this study. The compound 3 exhibited a pseudomolecular ion peak at $\mathrm{m} / \mathrm{z} 239,067\left[\mathrm{M}+\mathrm{H}^{+}\right]^{+}$in the HRESIMS corresponding to the molecular formula of $\mathrm{C}_{11} \mathrm{H}_{6} \mathrm{~N}_{6} \mathrm{O}$ and retention time of 1.3 min, compound 3 was identified as 3-Isocyanato-8-(4-pyridinyl)[1,2,4]triazolo [4,3-b] pyridazin. The compound $\mathbf{4}$ had a pseudomolecular ion peak at $\mathrm{m} / \mathrm{z} 203.06\left[\mathrm{M}+\mathrm{H}^{+}\right]^{+}$in the HRESIMS corresponding to the molecular formula of $\mathrm{C}_{12} \mathrm{H}_{10} \mathrm{O}_{3}$ with retention time of $1.8 \mathrm{~min}$, identified as biphenyltriol. The compound 8 showed a pseudo-molecular ion peak at $\mathrm{m} / \mathrm{z}$ $302.0874\left[\mathrm{M}+\mathrm{Na}^{+}\right]^{+}$in the HRESIMS corresponding to the molecular formula of $\mathrm{C}_{16} \mathrm{H}_{14} \mathrm{O}_{6}$ and retention time of 3.3 min, the compound 8 was identified as 3',5,7-Trihydroxy4'-methoxyflavanone. The compound $\mathbf{1 3}$ had a pseudomolecular ion peak of $\mathrm{m} / \mathrm{z} 362.3123\left[\mathrm{M}+\mathrm{Na}^{+}\right]^{+}$in the HESIMS corresponding to the molecular formula of $\mathrm{C}_{21} \mathrm{H}_{38} \mathrm{~N}_{4} \mathrm{O}$ with retention time of $5.1 \mathrm{~min}$, was identified as 8-[1-(1-Azepanyl)-2-propanyl]-2-(3-methylbutyl)-1,3,8triazaspiro[4.5]dec-1-en-4-one. The compound $\mathbf{1 7}$ showed a pseudo-molecular formula ion peak at $\mathrm{m} / \mathrm{z} 302.0874$ $\left[\mathrm{M}+\mathrm{Na}^{+}\right]^{+}$in the HRESIMS corresponding to the molecular formula of $\mathrm{C}_{21} \mathrm{H}_{20} \mathrm{O}_{10}$ and retention time of 5.9 , the compound 17 was identified as 3,8-Dihydroxy-6-methyl9,10-dioxo- 9,10-dihydro-1-anthracenyl beta-D-gluco pyranoside. The last one, the compound $\mathbf{2 0}$ exhibited a pseudo-molecular formula ion peak at $\mathrm{m} / \mathrm{z} \quad 463,12$ $\left[\mathrm{M}+\mathrm{Na}^{+}\right]^{+}$in the HRESIMS corresponding to the molecular formula of $\mathrm{C}_{22} \mathrm{H}_{22} \mathrm{O}_{11}$ with retention time of 6.4 was identified as soscoparin.

\section{Compound 3}

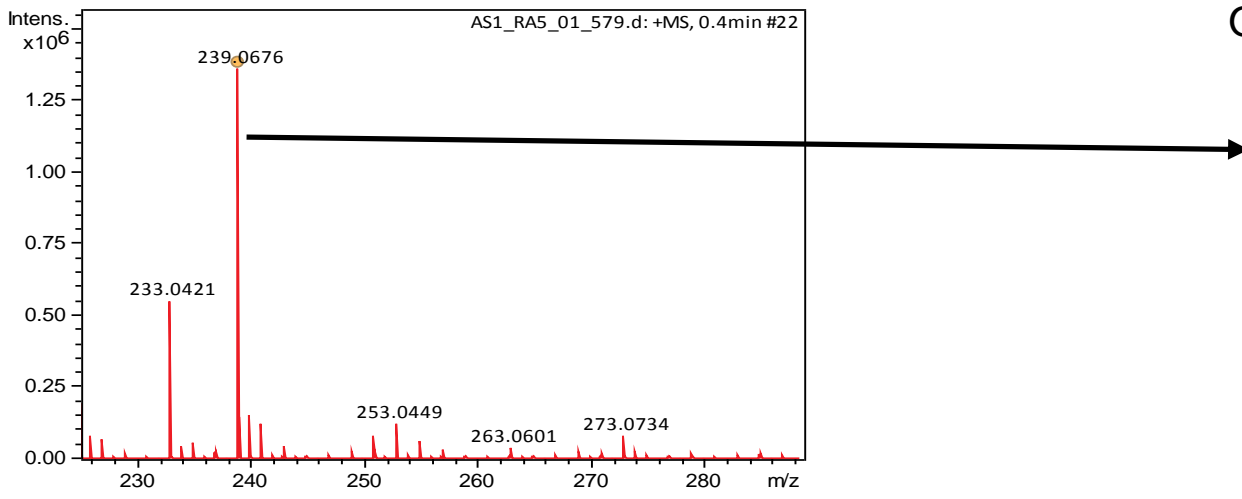<smiles>O=Nc1nnc2c(-c3ccncc3)ccnn12</smiles> 


\section{Compound 4}

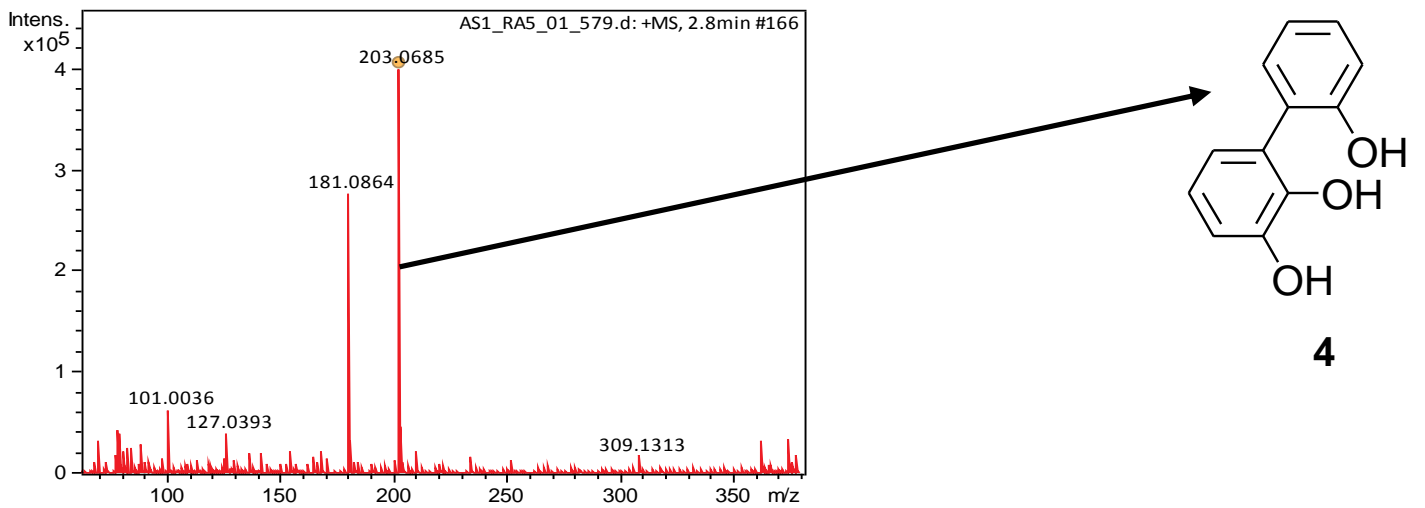

biphenyltriol

\section{Compound 8}

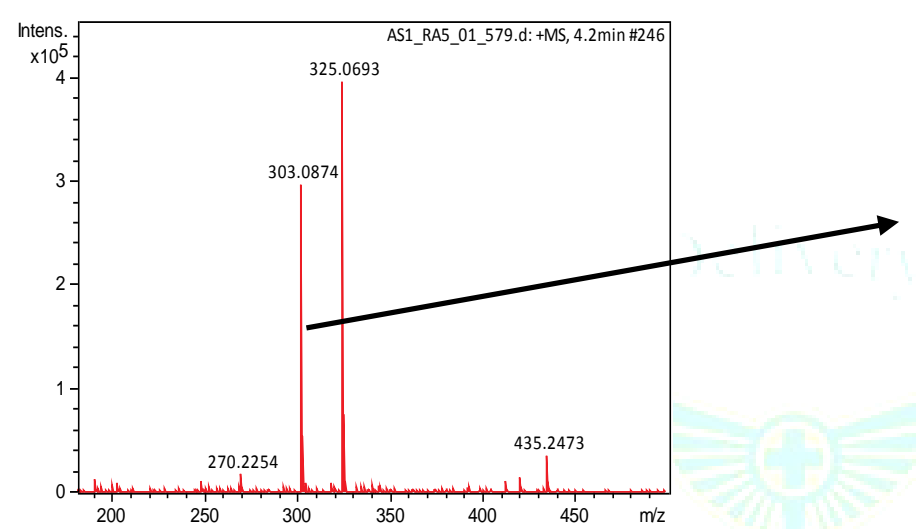<smiles>COc1ccc(C2CC(=O)c3c(O)cc(O)cc3O2)cc1O</smiles>

3',5,7-Trihydroxy-4'-methoxyflavanone

\section{Compound 13}

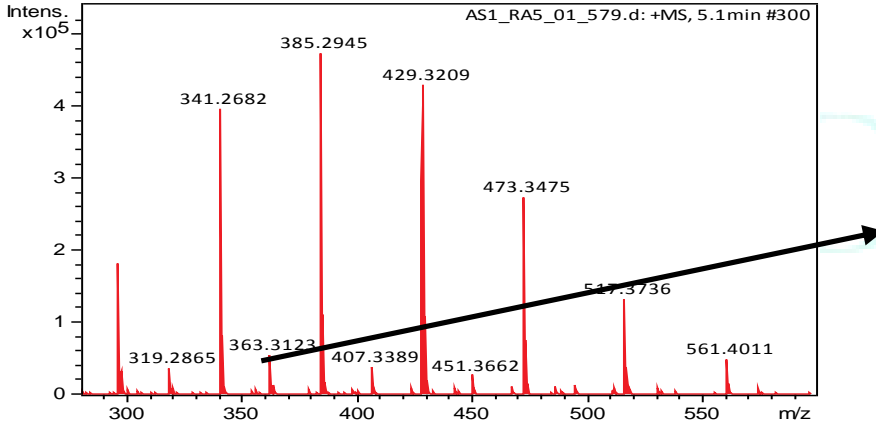<smiles>CC(C)CCC1=NC2(CCN(C(C)CN3CCCCCC3)CC2)CC(=O)N1</smiles>

13

8-[1-(1-Azepanyl)-2-propanyl]-2-(3-methylbutyl)-1,3,8-triazaspiro[4.5]dec-1-en-4-one

Compound 17

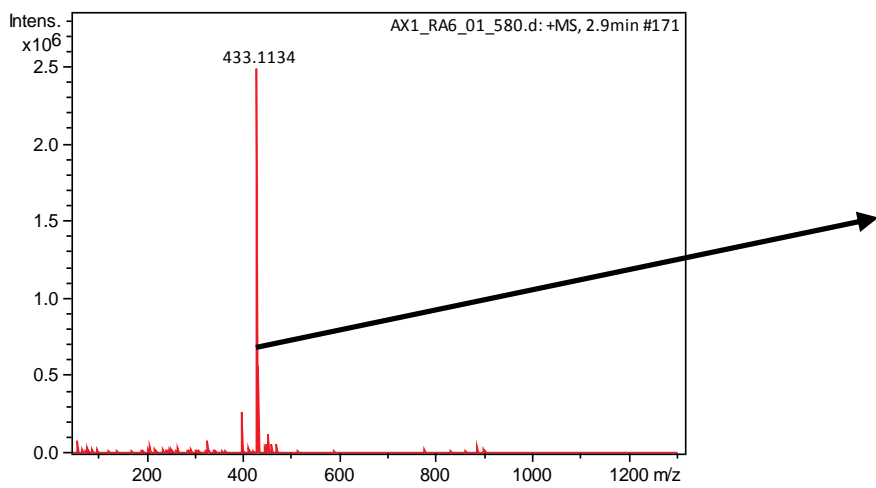<smiles>Cc1cc(O)c2c(c1)C(=O)c1cc(O)cc(Oc3cc(CO)c(O)c(O)c3O)c1C2=O</smiles>

3,8-Dihydroxy-6-methyl-9,10-dioxo-9,10-dihydro-1-anthracenyl beta-D-glucopyranoside 


\section{Compound 20}

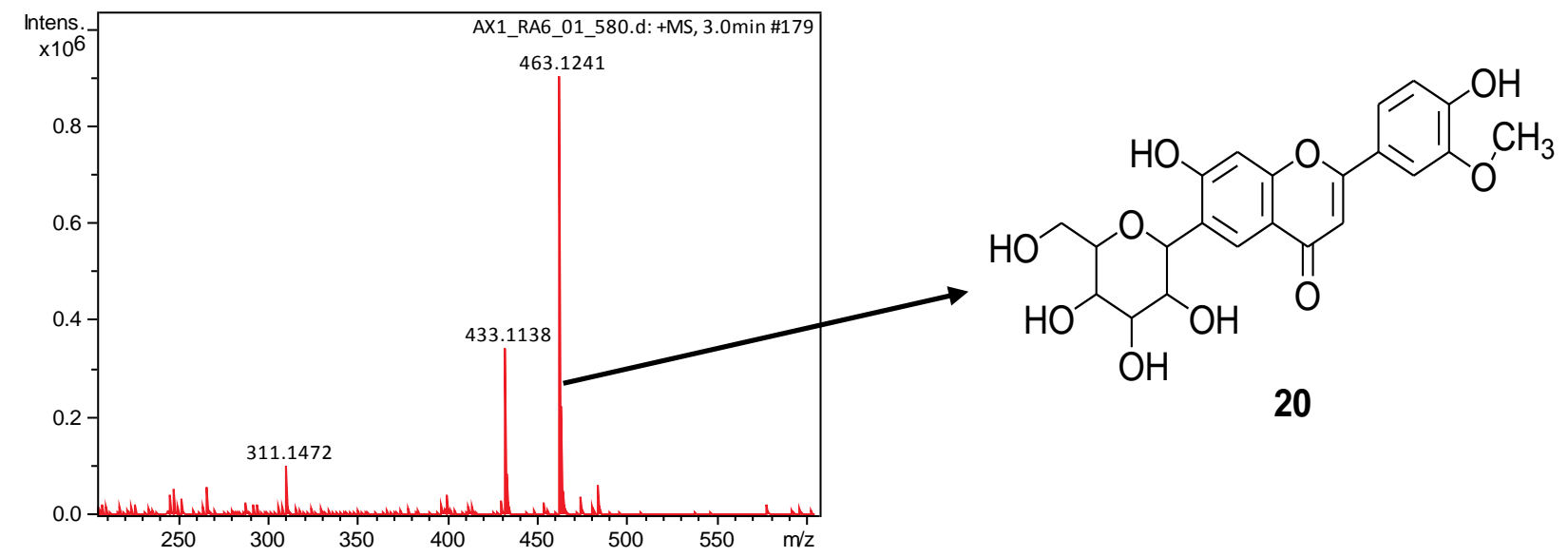

Soscoparin

\section{Anti-inflammatory activity}

\section{Ferrous oxidation-xylenol orange (Fox) assay}

Inhibition of 15-lipoxygenase by ASE using in vitro 15-Lox enzyme assay showed average inhibition of 15-Lox with IC 50 value of $37.19 \pm 0.54 \mu \mathrm{g} / \mathrm{mL}$ while the standard Quercetin with IC $_{50}$ value of $6.71 \pm 0.1931 \mu \mathrm{g} / \mathrm{mL}$ which is shown in figures 2 and 3

Inhibition of the 15 -lipoxygenase assay

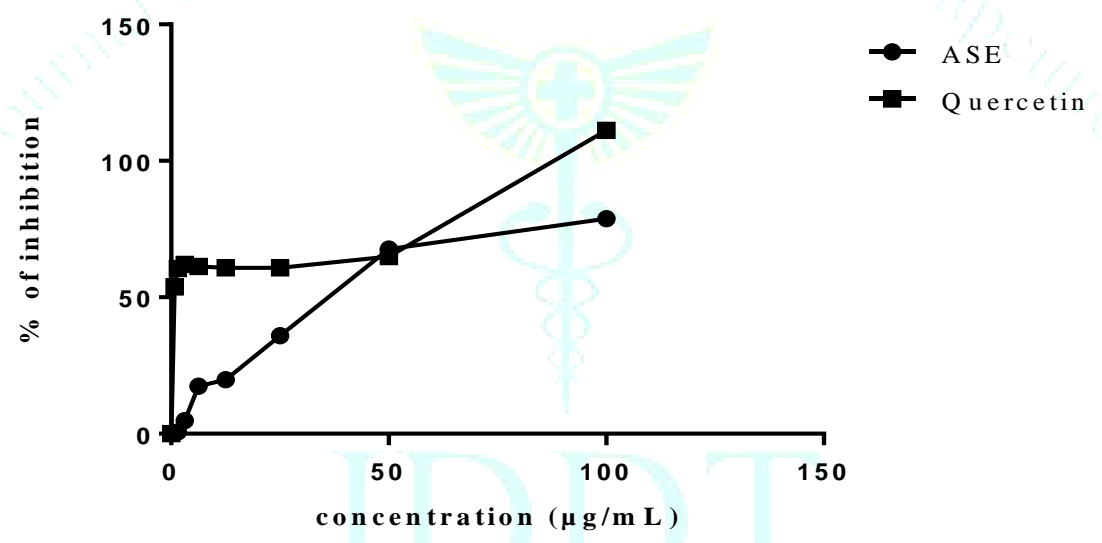

Figure 2: \% of Inhibition of the 15-lipoxygenase activity of ASE and Quercetin at different concentrations from which IC 50 values of OSE and Quercetin was obtained. Values are mean \pm SD of three experiments.

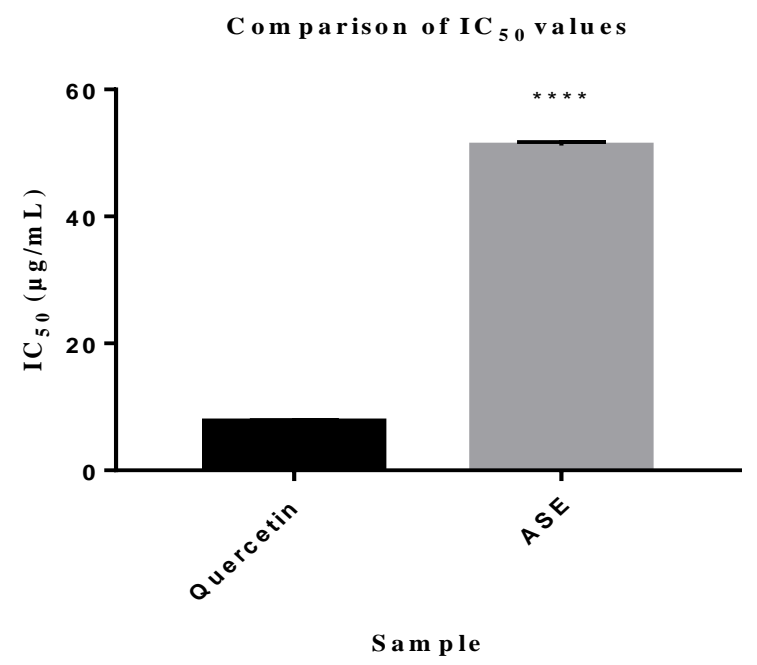

Figure 3: Comparison of $\mathrm{IC}_{50}$ of ASE with Quercetin. Data are expressed as mean $\pm \mathrm{SD}$, Quercetin was used as a reference compound. Statistical differences between quercetin and ASE as analyzed by the paired t-test $\left.{ }^{* * * *} P<0.0001\right)$. 


\section{Proteinase Inhibitory Action}

The ASE showed moderate inhibition of proteinase action with $\mathrm{IC}_{50}$ value of $244.33 \pm 2.08 \mu \mathrm{g} / \mathrm{mL}$ whereas for Aspirin, a standard drug had IC50 value of $53.79 \pm 2.61 \mu \mathrm{g} / \mathrm{mL}$ (figure's 4 and 5).

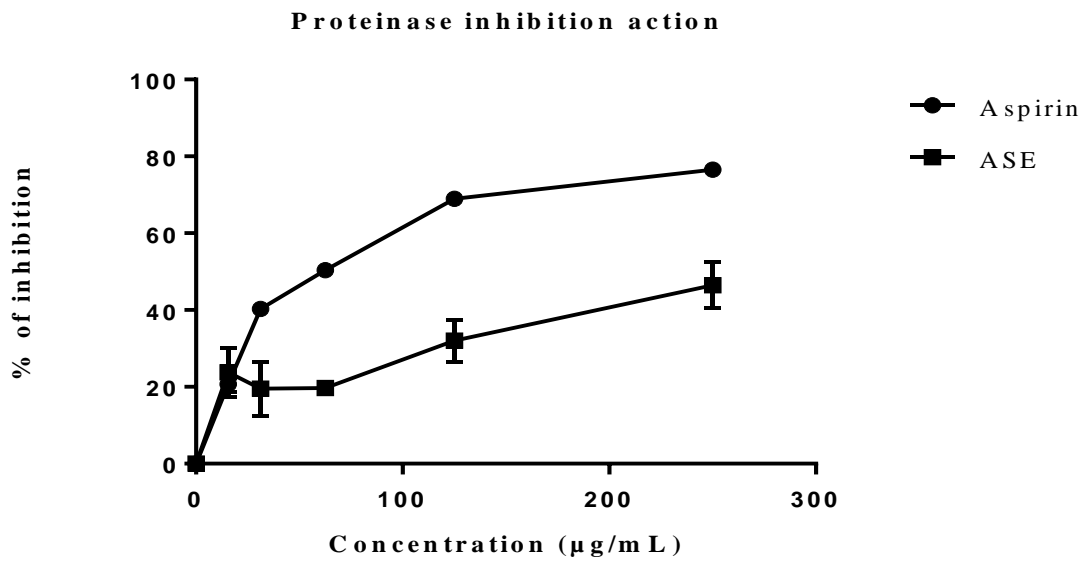

Figure 4: \% of Inhibition of the proteinase action of ASE and Aspirin at different concentrations from which $\mathrm{IC}_{50}$ values of ASE and Aspirin was obtained. Values are mean \pm SD of three experiments.

Com parison of $I_{50}$ values

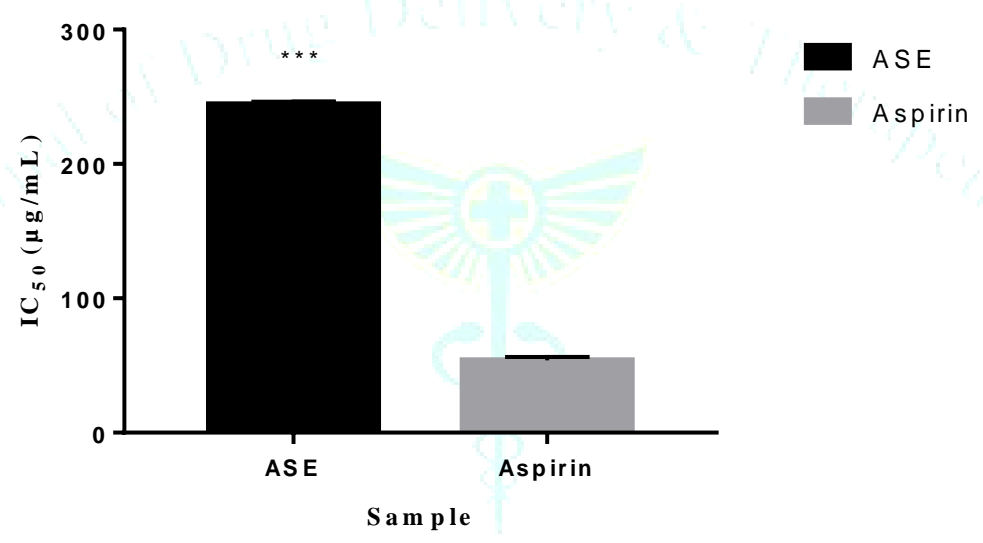

Figure 5: Comparison of $\mathrm{IC}_{50}$ of ASE with Aspirin. Data are expressed as mean $\pm \mathrm{SD}$, Aspirin was used as a standard drug. Statistical differences between Aspirin and ASE as analyzed by the paired t-test $\left({ }^{* * *} P<0.0001\right)$.

\section{Anti-arthritic activity}

The anti-denaturation study for investigating anti-arthritis activity was ascertained in this study using Bovine Serum Albumin (BSA) assay. The ASE displayed a strong inhibition activity of Bovine Serum Albumine denaturation with IC 50 value of $13.67 \pm 0.88 \mu \mathrm{g} / \mathrm{mL}$ as compared with that of the standard drug Diclofenac with $\mathrm{IC}_{50}$ value of $4.66 \pm 0.33 \mu \mathrm{g} / \mathrm{mL}$. The results were illustrated by the figures 6 and 7 .

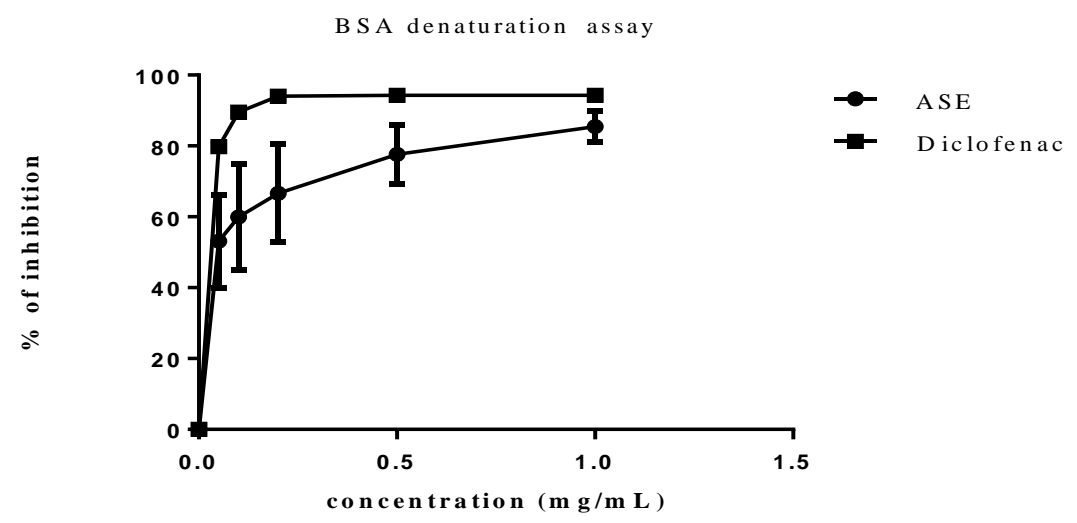

Figure 6: \% of Inhibition of the protein denaturation activity of ASE and Diclofenac sodium at different concentrations from which $\mathrm{IC}_{50}$ value of ASE and Diclofenac sodium was obtained. The error bars represent the standard deviation of measurement of the absorbance, experiment was done in triplicate. 


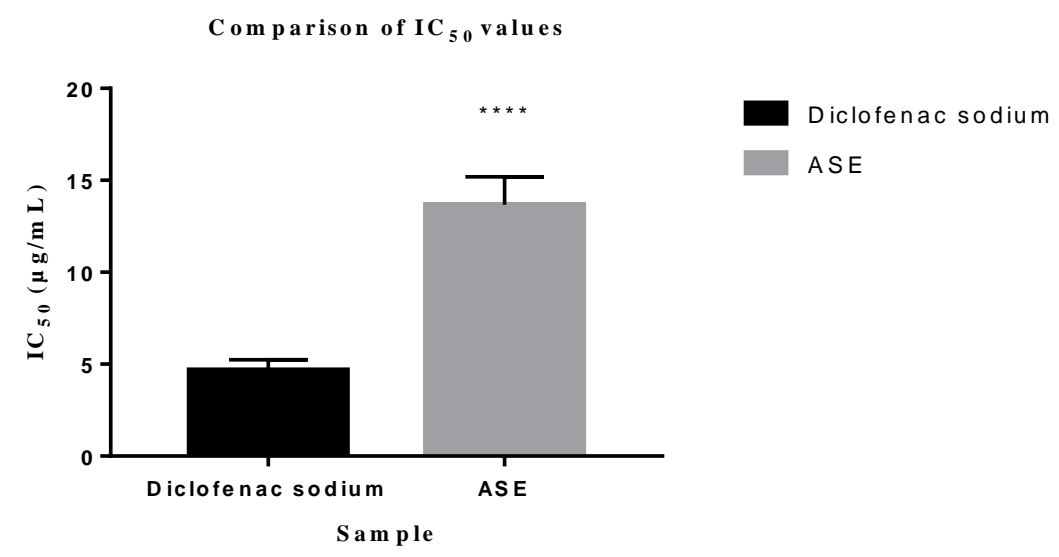

Figure 7: Comparison of $\mathrm{IC}_{50}$ of ASE with diclofenac sodium. Data are expressed as mean $\pm \mathrm{SD}$, Diclofenac sodium was used as a standard drug. Statistical differences between Diclofenac sodium and ASE as analyzed by the paired t-test $\left.{ }^{* * * *} P<0.0001\right)$.

\section{DISCUSSION}

We reported the identification of isocyanate, Soscoparin, biphenyltriol, methoxy-flavone, glycoside and flavonoids in the ASE. This result confirms literature review which revealed that Antocleista genus is a rich source of biocompounds such as alkaloids, xanthone, scoiridoids, and terpene ${ }^{24}$, contradicting in other hands to some author who reported that reducing sugar and glycosides were found to be absent in both the leaf and the stem-bark of the Anthocleista species ${ }^{25,26}$. Inflammation is induced by several pathway, one of the most pathway, it is initiated by the action of lipoxygenase on arachidonic acid producing trioxilins and leukotriene ${ }^{29}$. Agent which possess the ability of inibition of the 15-Lipoxygenase could be used as a potent anti-inflammatory agent. The anti-inflammatory effect was ascertained in this study by the inhibition of 15lipoxygenase and proteinase inhibition assays. Statistically $\left.{ }^{* * * *} P<0.0001\right)$ ASE showed selective inhibition of 15 lipooxygenase compared with that of the standard Quercetin. Proteinases have been implicated in arthritic reactions, it was previously reported that proteinase plays an important role in the development of tissue damage during in inflammatory reactions and significant level of protection was provided by proteinase inhibitors ${ }^{30}$. The present investigation has shown that, ASE had moderate proteinase inhibition action, statistically significant $\left.{ }^{(* * * *} P<0.0001\right)$ compared with that of the standard drug, Aspirin. There are several inflammatory study showing anti-inflammatory activity of the different parts of Anthocleista species. Analgesic properties of A. vogeli stem barks has been reported by Mbiantcha et al ${ }^{31}$, Baba and Usifoh $^{32}$ showed that the ethanol-water extract of $A$. djalonensis root revealed significant anti-inflammatory activity. The anti-lipoxygenase activity of ASE may be linked to the presence of biomolecules such as flavonoids, alkaloids and terpenes ${ }^{33}$. Flavonoids are known to interfere with the different stages of the arachidonate cascade via cyclooxygenase or lipoxygenase pathways to alleviate inflammatory responses ${ }^{34}$. Protein denaturation is one of the key features of inflammatory tissue and it undergoes denaturation and antigens are expressed which are associated with type-III hypersensitivity reaction, which in turn is related to diseases such as serum sickness, glomerulonephritis, rheumatoid arthritis and systemic lupus erythematosus 4,27,35. Mecanism of denaturation probably involves alterations in electrostatic, hydrogen, hydrophobic and disulphide bonding 34 . It is believed that agent that can help in anti-protein denaturation could be used as a potent anti-inflammatory drug in future ${ }^{28}$. The anti-denaturation study for investigating anti-arthritis activity was ascertained in this study using BSA assay. ASE had showed a strong in vitro anti-arthritic activity statistically significant $\left({ }^{* * *} P<0.0001\right)$ as compared with that of the standard drug Diclofenac. These findings support the traditional use of Anthocleista shweinfurthii as antiarthritic and in treatement of inflammatory disease in Cameroon.

\section{CONCLUSION}

Aqueous extracts of the bark of $A$. schweinfurthii was evaluated for their anti-arthritic and anti-inflammatory activities and their phytochemical study. The findings confirm the ethno medicinal use of $A$. schweinfurthii to manage the inflammation condition and arthritic. Isocyanate, biphenyltriol, methoxyflavanone, soscoparin and glucopyroside were identified in ASE. The isolation and characterization of these biomolecules and the understanding of the therapeutic targets of ASE will in the future allow the development of potential antiinflammatory agents from $A$. schweinfurthii bark.

\section{CONFLICT OF INTERESTS}

The authors declared that there is no conflict of interest regarding the publication of this paper.

\section{Acknowledgment}

Authors are very grateful to Cameroon National Herbarium (Yaounde) for identification of the plant. 


\section{REFERENCES}

1. Vane JR and Botting RM, New insights into the mode of action of anti-inflammatory drugs, Journal of Inflammation Research, 1995; 44(1):1-10.

2. Umapathy E, Ndebia EJ, Meeme B, Menzina P, Nkeh-Chungay BN, and Iputo JE, An experimental evaluation of Albuca seroseae aqueous extract on membrane stabilization, protein denaturation and white blood cell migration during acute inflammation, Journal of Medicinal Plant Research, 2010; 4(9):789-795.

3. Harsh Mohan. Text book of pathology. 6th ed. Jaypee publications ; 2010 . P. 851.

4. Kishore G, Siva G, Sindhu ES, in Vitro Anti-Inflammatory and Anti-Arthritic Activity of Leaves of Physalis Angulata L, international journal pharmaceutical ind research, 2011; 1:211-213.

5. Kumar V, Bhat ZA, Kumar D, Bohra P, and Sheela S, in vitro antiinflammatory activity of leaf extracts of Basella alba Linn.Var Alba, International Journal of Drug Development and Research, 2011; 3(3):176-17.

6. Deepika A, Mukesh M, Neha G and Vidya $P$, In vitro antiinflammatory and anti-arthritic activity in methanolic extract of cocculus hirsutus. Diels. In vivo and in vitro, International journal of pharmaceutical Science and research, 2014; 5(5):1957-1962.

7. Corley DA, Kerlikowske K, Verma R, Buffler P, Protective association of aspirin/ NSAIDs and esophageal cancer, a systematic review and meta-analysis. Gastroenterology. 2003; 124(1):47-56.

8. Ruijter A, Anthocleista schweinfurthii Gilg. In Schmelzer, G.H. \& Gurib-Fakim, A. (Editors). PROTA (Plant Resources of Tropical Africa), Wageningen, Netherlands. 2007.

9. Christophe M, Frida L, Cline N, Zacharie S, Emilie N, Vernyuy PT, Evaluation of acute and subacute toxicity of stem bark aqueous extract of Anthocleista schweinfurthii (Loganiaceae), World journal of pharmacy and pharmaceutical sciences, 2015; 4:197-208.

10. Burkill HM, The useful plants of West Tropical Africa. 2nd Edition. Volume 3, Families J-L. Royal Botanic Gardens, Kew, Richmond, United Kingdom ; 1995. P.857.

11. Fowler DG, Traditional Fever Remedies: A List of Zambian plants. http// www.Gift.org/ritam/news/Traditional_Fever_remedies1.Pdf (accessed 20.04.2016)

12. Schmelzer GH, In Schmelzer GH, Gurib-Fakim A, (Eds.), Arroo R, (Associate Ed.) Lemmens RHMJ, Oyen LPA, (General Ed.), Plant Resources of Tropical Africa: Medicinal plants, 2008; 11:1.

13. Gbadamosi IT and Erinoso SM, A review of twenty ethnobotanicals used in the management of breast cancer in Abeokuta, Ogun State, Nigeria. Afican Journal of pharmacy and Pharmacology, 2016; 10(27):546-564.

14. Adongo SO, Morongo J, Anjou R, New Analysis of selected essential elements of medicinal plants used by Chuka community, Tharaka Nithi county, Kenya, Science Journal Technology Special issue, 2012; 87-94.

15. Djova SV, Nyegue MA, Afagnigni $\mathrm{AD}$, Etoa $\mathrm{FX}$, In vitro antioxidant activity, cytotoxicity and genotoxicity of extracts from the leaves and barks of Anthocleista schweinfurthii gilg (loganiaceae), Asian Journal of Research in Biological and Pharmaceutical Sciences, 2018 ; 6(2):58-69.

16. Djeussi DE, Noumedem JAK, Kuete V, Ngadjui BT, Antibacterial and antibiotic-modulation activity of six Cameroonian medicinal plants against Gram-negative multi-drug resistant phenotypes, BMC complementary and alternative medicine, $2016 ; 16: 124$

17. Ngombe NK, Kalenda DT, Quetin-Leclercq J, Morel N, Vasoconstrictor and inotropic effects induced by the root bark extracts of Anthocleista schweinfurthii. Natural product communications, 2010; 5(3):369-72.

18. Mbouangouere RN, Tane P, Ngamga D, Khan SN, Choudhary MI, Ngadjui BT, A new steroid and $\alpha$-glucosidase inhibitors from Anthocleista schweinfurthii, Research Journal of Medicinal Plant, 2016; 1(3):106-111, DOI:10.3923/rjmp.2007.106.11.
19. Abay G, Altun M, Koldas S, Tüfekci AR, Demirtas I, Determination of antiproliferative activities of volatile contents and HPLC profiles of Dicranum scoparium (Dicranaceae, Bryophyta), Combinatorial Chemistry High Throughput Screening, 2015; 18(5):453-63.

20. Pinto MC, Tejeda A, Duque AL, Macias P, Determination of lipoxygenase activity in plant extracts using a modified ferrous oxidation. Xylenol orange assay, Journal Agricultural and Food Chemistry, 2007; 55(595):6-9.

21. Delong JM, Prange RK, Hodges DM, Forney CF, Bishop MC, and Quilliam M, Using a Modified Ferrous Oxidation-Xylenol Orange (FOX) Assay for Detection of Lipid Hydroperoxides in Plant Tissue, Journal of Agricultural and Food Chemistry, $2002 ; 50(2): 248-254$.

22. Oyedapo 00 and Famurewa AJ, Antiprotease and membrane stabilizing activities of extracts of Fagara Zanthoxyloides, Olax subscorpioides and Tetrapleura tetraptera, International journal of Pharmacognosy, 1995 ; 33:65-69.

23. Sakat SS, Juvekar AR, Gambhire MN, In-vitro antioxidant and anti-inflammatory activity of methanol extract of Oxalis corniculata Linn, International Journal of Pharmacy and Pharmaceutical sciences, 2010; 2(1):46-55.

24. Irvine FR, Woody Plants of Ghana. Oxford University Press, London, UK.1961.

25. Njayou FN, Moundipa PF, Tchana AN, Ngadjui BT, Tchouanguep FM, Inhibition of microsomal lipid peroxydation and oxideation by extrats from plants used in Bamum folk medicine (Cameroon) againts hepatitis, African journal of traditional, complementary and alternative medicines, 2008; 278-289.

26. Jegede IA Ibrahim JA Kunle OF, Phytochemical and pharmacognostic studies of the leaf and stem-bark of Anthocleista vogelii (Planch), Journal of medicine plant research, 2011; 5:61366139. http://dx.doi.org/10.5897/jmpr10.404.

27. Leelaprakash G, Dass SM, In-vitro anti-inflammatory activity of methanol extract of Enicostemma axillare, International Journal of Drug Delivery Research, 2011; 3:189-196.

28. Tabiri I, Henneh, Akrofi R, Ofori AE, Konja D, Owusu G, Abane B, Acquah-Mills J, Edzeameh JF and Tayman F, Stem Bark Extract of Sterculia setigera Delile Exhibits Anti-inflammatory Properties through Membrane Stabilization, Inhibition of Protein Denaturation and Prostaglandin E2 Activity, International Journal of Pharmaceutical Research, 2018; 22(5):1-11.

29. Wisastra R, Dekker FJ, Inflammation, cancer and oxidative lipoxygenase activity are intimately linked, Cancers (Basel), 2014; 6(1):500-521.

30. Das SN, Chatterjee S. Long term toxicity study of ART-400, Indian Journal of Indigenous Medicines, 1995, 16(2):117-123.

31. Mbiantcha M, Nguessom KO, Ateufack G, Oumar M, Kamanyi A Analgesic properties and toxicological profile of aqueous extract of the stem bark of Anthocleista vogelli Planch, International Journal of pharmaceutical, chemical and Biological Sciences, 2013; 1:1-12.

32. Baba H, Usifoh CO, Phytochemical investigation and antiinflammatory property of ethanol-water extract of the roots of Anthocleista djalonensis A. Chev. (Gentianiaceae). African Journalof Biotechnology, 2011; 10:6598-6600.

33. Mulaudzi RB, Ndhlala AR, Kulkarni MG, Finnie JF, Staden Van J, Anti-inflammatory and mutagenic evaluation of medicinal plants used by Venda people against venereal and related diseases, Journal of Ethnopharmacology, 2013; 146(1):173179

34. McGaw LJ, Elgorashi EE, Eloff JN, Cytotoxicity of African Medicinal Plants against Normal Animal and Human Cells, Toxicological Survey of African Medicinal Plants. Elsevier, London, 2014.

35. Arya D and Patni V, Comparative analysis of in vitro antiinflammatory and anti-arthritic activity in methanolic extract of Pluchea lanceolata Oliver \& Hiern. In vivo and in vitro, International Journal of Biological and Pharmaceutical Research, 2013, 4(9):676-680. 